\title{
Real-time Radiation Monitoring and Assessment of Radiation Risk on Public around BSMMU Hospital Campus, Dhaka, Bangladesh
}

\author{
A Tareque1, S. K. Das², M. S. Rahman ${ }^{3 *}$, S. Yeasmin ${ }^{4}$ \\ ${ }^{1,2}$ Department of Physics, Jagannath University, Dhaka-1100, BANGLADESH \\ ${ }^{*} 3,4$ Health Physics Division, Atomic Energy Centre, Shahbag, Dhaka-1000, BANGLADESH \\ *(msrahman1974@yahoo.com)
}

This journal is licensed under a Creative Commons Attribution-Noncommercial 4.0 International License (CC-BY-NC). Articles can be read and shared for noncommercial purposes under the following conditions:

- BY: Attribution must be given to the original source (Attribution)

- NC: Works may not be used for commercial purposes (Noncommercial)

This license lets others remix, tweak, and build upon your work non-commercially, and although their new works must also acknowledge you and be non-commercial, they don't have to license their derivative works on the same terms. License Deed Link: http://creativecommons.org/licenses/by-nc/4.0/ Legal Code Link: http://creativecommons.org/licenses/by-nc/4.0/legalcode $A B C$ Research Alert uses the CC BY-NC to protect the author's work from misuse.

\section{Abstract}

Objective: Ionizing radiation is extensively used in the hospital for diagnosis and treatment procedures to patients and its usage increasing day by day with the socio-economic development of the country. The aim of the study is to monitor the real-time radiation around the Bangabandhu Sheikh Mujib Medical University (BSMMU) hospital campus and estimation of the radiation risk on public.

Method: The real-time radiation monitoring around the BSMMU hospital campus was performed using digital portable radiation monitoring device (DPRMD). The DPRMD meets all European CE standards and the American "FCC 15 standard". The DPRMD was placed at 1 meter above the ground on tripod and data taking time for each monitoring point (MP) was 1 hour. Each MP was identified using Garmin eTrex GPS device. 32 MPs were selected for taking the real-time radiation dose rates around the BSMMU hospital campus from August-September 2019.

Results: The real-time radiation dose rates around the BSMMU hospital campus were ranged from 0.020-2.45 $\mu \mathrm{Sv} / \mathrm{hr}$ with an average of $0.211 \pm 0.094 \mu \mathrm{Sv} / \mathrm{hr}$. The annual effective dose on public were ranged from 0.222 $\pm 0.052 \mathrm{mSv}$ to $1.247 \pm 0.071 \mathrm{mSv}$ with an average of $0.368 \pm 0.097 \mathrm{mSv}$. The excess life-time cancer risk (ELCR) on public was estimated based on the annual effective dose that ranged from $0.881 \times 10^{-3}$ to $5.12 \times 10^{-3}$ with an average value of $1.488 \times 10^{-3}$ around the BSMMU hospital campus, which means that in every thousand people, one person is at the risk of developing cancer caused by the scattered radiation exposure from the hospital. Conclusion: Real-time radiation monitoring makes possible to ensure the protection the radiation worker and the public from unnecessary radiation hazard. The study also provides the instantaneous information of inappropriate operation of radiation generating equipments and improper handling of radioactive substances in the hospital.

\section{Keywords}

Ionizing radiation, In-Situ, Hospital, Public, Cancer.

\section{INTRODUCTION}

Medical procedures using ionizing radiation have both risks and benefits. At present, scientific articles predict thousands of new cancers occurring from the CT scan and other radiation related imaging procedures (University of California SF, 2021). Ionizing radiation is in all places and the average annual 
effective dose per person in the United Sates is about $6.2 \mathrm{mSv}$ (NCRP, 2009). Worldwide average natural background radiation level is approximately $2.4 \mathrm{mSv}$ per year (UNSCEAR, 2000). Natural background radiation level contributes from the geological characteristics of a site such as altitude, latitude of the place, etc. Public gets ionizing radiation from naturally occurring gamma emitting radioisotopes. The key gamma emitting naturally occurring radioisotopes are ${ }^{40} \mathrm{~K},{ }^{232} \mathrm{Th} \&{ }^{238} \mathrm{U}$ series with their daughter products and those exist in soil, water, rocks and construction materials. In-situ radiation dose rate monitoring is reliable at indoor and outdoor environments (Hazrati S. et al., 2010), (Ateba J. F. B. et al., 2010). Many developed countries with superior health care system, medical radiation doses are the most important single source of ionizing radiation to public (UNSCEAR, 2008).

Mean ionizing radiation dose of the United States people has risen twice over the last 30 years (Brenner DJ, 2007; Mettler FA Jr, 2009). Though mean radiation dose at a certain place from natural sources has not changed but average radiation dose from medical imaging procedures have raised 6 times (Brenner DJ, 2007; Mettler FA Jr, 2009). Medical imaging procedures contribute approximately $50 \%$ of the total radiation dose to the people of the United States comparing to about 15\% in 1980 (Mettler FA Jr, 2009). The maximum contributor to this fast increasing in public exposure in United States is the Computed Tomography (CT) scan. Though CT scan is responsible for greater part of the rapidly increasing in public exposure from medical imaging, other imaging modalities \& nuclear medicine procedures are also increasing speedily, particularly in cardiology (Mettler FA Jr, 2009).

Radiation exposure to public contributes from contact with patients undergoing either treatment or diagnosis procedures that use sealed and unsealed radionuclides. Radiation exposure to public is also giving from the disposal of radioactive waste from the hospitals \& production of radionuclides for medicine (UNSCEAR, 2008). There are approximately 3.6 billion diagnostic radiology X-ray examinations carrying out annually in the worldwide (UNSCEAR 2008). Among diagnosis X-ray examinations, CT scan adds more radiation dose to worker \& public and $34 \%$ of collective dose giving from the CT examinations alone out of all medical radiation exposures (UNSCEAR, 2000). CT scan only contributes $43 \%$ of the total collective effective dose from diagnosis X-ray examinations in the hospital (UNSCEAR, 2008).

The BSMMU hospital is situated at the Shahbag of Dhaka city \& three large academic establishments of the country such as University of Dhaka, Bangladesh University of Engineering \& Technology, Dhaka Medical College Hospital are only $1.0 \mathrm{~km}, 2.1 \mathrm{~km}, 1.6 \mathrm{~km}$ away from the BSMMU respectively. The BSMMU hospital has many departments, namely National Institute of Nuclear Medicine \& Allied Sciences, Cardiology, Clinical Oncology, Radiology \& Imaging, Surgery, Dentistry, etc. The objective of the study is to monitor the real-time radiation dose rate around the BSMMU hospital campus following the In-Situ Method and assessment of excess life-time cancer risk (ELCR) on public who are residing nearby the BSMMU hospital campus based on the real-time radiation monitoring data.

\section{MATERIALS AND METHODS}

\section{Description of the monitoring instrument}

A real-time digital portable radiation monitoring device which is called as GAMMA SCOUT was used for this study. GAMMA SCOUT is designed and manufactured by Germany, built with a solid Novadur exterior. An optional stylish leather holster with belt strap can further protect the GAMMA SCOUT from the elements. The GAMMA SCOUT is a Geiger counter with a form fitting ergonomic shape. The device has a battery indicator, multiple unit conversion, real-time dose rate and cumulative dose display functions and programmable logging and alert functions. Advanced functions include PC data download via USB cable and an ultra-low current power circuit for extended battery life. GAMMA-SCOUT reports the input of radioactivity fast, reliably, and permanently.

The conversion of pulses per minute to dose rate depends on the level of pulse input. Under environmental input (about $0.200 \mu \mathrm{Sv} / \mathrm{h}$ ) the conversion is $142 \mathrm{pulses} /$ minute $=1.0 \mu \mathrm{Sv} / \mathrm{h}$ (User Manual-GAMMA SCOUT, 2014). Gamma-Scout also provides information on the cumulative dose 
received by the device, measured on the time axis. GAMMA-SCOUT w/ALERT features can acoustic signal that sounds when the dose rate exceeds a specific level. The default alert level is $5 \mu \mathrm{Sv} / \mathrm{h}$. If this value is exceeded by measurement of radioactivity, this will be shown with an additional symbol in the display. The symbol in the display can be erased by pressing the button twice. Individual Programming of Dose Rate Alert Level by pressing the button once to switch to the "log frequency" mode. The lowest possible threshold setting is $0.1 \mu \mathrm{Sv} / \mathrm{h}$, the maximum is $2 \mathrm{mSv} / \mathrm{h}$. The step change is $0.1 \mu \mathrm{Sv} / \mathrm{h}$ at the lower level, becoming higher up the range.

\section{Calibration of the monitoring instrument}

In typical environmental radiation, the counter tube is not subject to fatigue and so, it will not require re-calibration. But, if the user has ISO certification, periodical calibration is needed. To sub-contract to an assembly operation, this tests it for 72 hours against a master. The master is calibrated against a gauged reference source (Cs-137). A data log is then generated.

The GAMMA SCOUT was calibrated inbuilt by the manufacturer. The GAMMA SCOUT is also calibrated at the Secondary Standard Dosimetry Laboratory (SSDL) under the Bangladesh Atomic Energy Commission (BAEC) using gamma-ray standard sources such as ${ }^{137} \mathrm{Cs}$, ${ }^{60} \mathrm{Co}$, etc. and X-ray Unit. The SSDL of BAEC has been available since 1991, which is traceable to the Primary Standard Dosimetry Laboratory (PSDL) of National Physical Laboratory (NPL), UK. The SSDL of BAEC has $\mathrm{X}$-ray Unit $(30 \mathrm{kV}-225 \mathrm{kV})$ for radiation generating equipments calibration.

The performance of BAEC's SSDL is maintained according to the requirements of the International Atomic Energy Agency (IAEA)/World Health Organization (WHO) network of SSDLs. Therefore, the evaluated doses are traceable to the International measurement system. The GAMMA SCOUT accurately measure dose rate in the range of 0.01-5000 $\mu \mathrm{Sv} / \mathrm{hr}$ (User Manual-GAMMA SCOUT, 2014).

\section{Real-time Radiation Data collection}

The real-time radiation monitoring around the BSMMU hospital campus was carried out in August-September 2019. The real-time radiation monitoring around BSMMU hospital campus was conducted because public receive radiation from the hospital where various types of ionizing radiation generating equipments such as X-ray Machines, CT scanners, Fluoroscopy, etc. used for diagnosis and treatment procedures to patients in each day.

The real-time radiation monitoring was performed at 32 selected locations around the BSMMU hospital campus and time for data collection at each monitoring point (MP) was about 1 hour. The GAMMA SCOUT was placed on a tripod at 1 meter height from the ground level. The MP was marked out using a GARMIN eTrex GPS device. The unit uses the proven performance of Garmin high-sensitivity GPS and full-featured mapping to create an unsurpassed portable GPS receiver (Owner's Manual-GARMIN eTrex HC Series, 2007).

\section{Description of the monitoring site}

The study area is located from N: 23.74094 to N: 23.73862 and from E: 090.39404 to E: 90.39496 . BSMMU hospital has five main multistoried buildings that are identified as Block-A, Block-B, BlockC, Block-D and Block -E as Cabin block respectively (BSMMU website, 2020). Block-A is a 7 storied building and accommodates the library, lecture theater, auditorium, hospital record section, students hostel, dental faculty and blood transfusion services.

The library has a fairly large collection of current and old volumes of periodicals, textbooks, monographs and other related material. Block-B is a 6 storied building which at its eastern wing accommodates the office of the Vice-Chancellor, administrative block, Controller Office, reception, conference hall, radiology department, digital library, hospital kitchen, maintenance department stores, endoscopy room, CT scan \& MRI room, residential accommodation for the duty doctors and nurses. The western part of Block-B is a 9 storied building and accommodates all the departments of basic medical sciences such as Anatomy, Physiology, Biochemistry, Pharmacology, Pathology, Hematology, Virology and Microbiology. A one-stop laboratory services is located at the ground floor. 
The animal house is located near this B-block in a separate building. Block-C is the 10 storied main hospital building. This block accommodates the Office of the Director of hospital and his administration, reception, telephone exchange, departments of Physical medicine, Pediatrics, Neonatology, Pediatric neurology, Pediatric surgery, Clinical pathology, Dermatology, Nephrology, Urology, Neurology, Neuro-Surgery, Ophthalmology, ENT, Obstetrics \& Gynecology, Surgery, Hepatobiliary Surgery, Lithotripsy room, Operation theater, Anesthesiology, Pain clinic, Intensive Care Unit (ICU) \& Post-operative ward. Block-D is the 18 storied building (under construction).

This block accommodates the Emergency, Casualty, Cardiac emergency, Obstetrics \& Gynecology emergency, Orthopedics emergency, Cardiology, Cath Lab, CCU, Cardiac surgery, Vascular surgery, Pediatric hematology \& Oncology, Pediatric Cardiology, Pediatric Gastroenterology, Hepatology, Orthopedics, Phychiatry, Gastroenterology, Hematology, Medicine, Oncology \& National Institute of Nuclear Medicine and Allied Sciences (NINMAS) a joint project of Bangladesh Atomic Energy Commission and BSMMU.

The NINMAS has modern diagnostic and therapeutic facilities including computerized ultrasonography, gamma camera and a well-equipped radioimmunoassay (RIA) laboratory. This is considered to be the best center for non-invasive diagnoses. Block-E is Cabin Block, OPD 1 \& OPD 2. The causality department, out-patient departments for Medicine, Surgery, Neuro surgery, Neurology, Gastroenterology, Hematology, Psychiatry, Pediatric surgery and Hospital dispensary are located in a separate complex.

\section{Calculation of annual effective dose and ELCR}

United Nations Scientific Committee on the Effects of Atomic Radiation (UNCEAR, 1988) recommended the outdoor occupancy factor of 0.20 to public. This occupancy factor is the proportion of the total time during which an individual is exposed to a radiation at outdoor. The outdoor annual effective dose to public due to ionizing radiation is calculated by the equation below:

Annual effective dose $(\mu S v)=$ dose rate $\left(\mu S v . \mathrm{hr}^{-1}\right) \times 0.2 \times 8760 \mathrm{hr} . \mathrm{yr}^{-1}$

Excess life-time cancer risk factor (ELCR) is calculated by the equation below:

$$
E L C R=A E D \times D L \times R F
$$

Where AED is annual effective dose to public, DL is the duration of life of Bangladeshi people (World Bank Report, 2018) and RF is the risk factor $\left(\mathrm{Sv}^{-1}\right)$, it is a fatal cancer risk per Sievert. For stochastic effects from low dose radiation, ICRP 103 suggested the value of 0.057 for the public exposure (ICRP, 2007).

\section{RESULTS AND DISCUSSION}

\section{Annual effective dose}

The real-time radiation dose rates around the BSMMU hospital campus were ranged from 0.020-2.45 $\mu \mathrm{Sv} / \mathrm{hr}$ with an average of $0.211 \pm 0.094 \mu \mathrm{Sv} / \mathrm{hr}$. The annual effective dose on public around the BSMMU hospital campus were ranged from $0.222 \pm 0.052 \mathrm{mSv}$ to $1.247 \pm 0.071 \mathrm{mSv}$ with an average of $0.368 \pm 0.097 \mathrm{mSv}$. The real-time radiation monitoring around the hospital campus would facilitate to ensure the safety of the radiation worker, public \& the patients and also gives an instant signal of erroneous use of technical parameters of radiation generating equipments or equipment malfunction.

Additionally, the real-time radiation monitoring is also important for calculation of optimum shielding against ionizing radiation that prevent the scattered radiation. The radiation worker \& public get maximum ionizing radiation dose from the scattered radiation in the hospital. Table-1 shows the realtime radiation dose rate monitoring at 32 locations around the BSMMU hospital campus in AugustSeptember 2019. 


\begin{tabular}{|c|c|c|c|c|c|}
\hline \multirow{2}{*}{$\begin{array}{l}\text { SL } \\
\text { no. }\end{array}$} & \multirow{2}{*}{$\begin{array}{l}\text { Latitude/ } \\
\text { Altitude }\end{array}$} & \multicolumn{3}{|c|}{$\begin{array}{c}\text { Radiation dose rate } \\
(\mu \mathrm{Sv} / \mathrm{hr})\end{array}$} & \multirow{2}{*}{$\begin{array}{l}\text { Annual effective } \\
\text { dose due to radia- } \\
\text { tion }(\mathrm{mSv}) \pm \mathrm{SD}\end{array}$} \\
\hline & & Range & Mean & SD & \\
\hline 1 & $\begin{array}{l}\text { N } 23044.472^{\prime} \\
\text { E } 90023.751^{\prime}\end{array}$ & $0.226-0.346$ & 0.283 & 0.038 & $0.497 \pm 0.066$ \\
\hline 2 & $\begin{array}{l}\text { N } 23044.476^{\prime} \\
\text { E } 90023.735^{\prime}\end{array}$ & $0.151-0.266$ & 0.208 & 0.037 & $0.364 \pm 0.064$ \\
\hline 3 & $\begin{array}{l}\text { N } 23044.480^{\prime} \\
\text { E } 90023.720 \\
\end{array}$ & $0.151-0.282$ & 0.215 & 0.041 & $0.377 \pm 0.072$ \\
\hline 4 & $\begin{array}{l}\text { N } 23044.475^{\prime} \\
\text { E } 90023.705^{\prime}\end{array}$ & $0.158-0.366$ & 0.246 & 0.058 & $0.430 \pm 0.102$ \\
\hline 5 & $\begin{array}{l}\text { N } 23044.475^{\prime} \\
\text { E } 90023.690^{\prime}\end{array}$ & $0.151-0.306$ & 0.227 & 0.048 & $0.398 \pm 0.085$ \\
\hline 6 & $\begin{array}{l}\text { N } 23044.470^{\prime} \\
\text { E } 90023.663^{\prime}\end{array}$ & $0.288-0.332$ & 0.265 & 0.043 & $0.464 \pm 0.075$ \\
\hline 7 & $\begin{array}{l}\text { N } 23044.464^{\prime} \\
\text { E } 90023.646\end{array}$ & $0.173-2.45$ & 0.712 & 0.827 & $1.247 \pm 1.45$ \\
\hline 8 & $\begin{array}{l}\text { N } 23044.466 \\
\text { E } 90023.642\end{array}$ & $0.188-0.323$ & 0.255 & 0.043 & $0.447 \pm 0.076$ \\
\hline 9 & $\begin{array}{l}\text { N } 23044.311^{\prime} \\
\text { E } 90023.751^{\prime}\end{array}$ & $0.180-0.315$ & 0.247 & 0.042 & $0.432 \pm 0.074$ \\
\hline 10 & $\begin{array}{l}\text { N } 23044.345^{\prime} \\
\text { E } 90023.757^{\prime}\end{array}$ & $0.165-0.340$ & 0.238 & 0.050 & $0.416 \pm 0.087$ \\
\hline 11 & $\begin{array}{l}\text { N } 23044.374 \\
\text { E } 90023.743^{\prime}\end{array}$ & $0.151-0.393$ & 0.256 & 0.065 & $0.448 \pm 0.114$ \\
\hline 12 & $\begin{array}{l}\text { N } 23044.389^{\prime} \\
\text { E } 90023.754^{\prime}\end{array}$ & $0.151-0.315$ & 0.231 & 0.051 & $0.405 \pm 0.089$ \\
\hline 13 & $\begin{array}{l}\text { N } 23044.410^{\prime} \\
\text { E } 90023.758^{\prime}\end{array}$ & $0.165-0.332$ & 0.247 & 0.051 & $0.433 \pm 0.090$ \\
\hline 14 & $\begin{array}{l}\text { N } 23044.432 \\
\text { E } 90023.777^{\prime}\end{array}$ & $0.173-0.299$ & 0.235 & 0.040 & $0.411 \pm 0.069$ \\
\hline 15 & $\begin{array}{l}\text { N } 23044.453^{\prime} \\
\text { E } 90023.772^{\prime}\end{array}$ & $0.196-0.306$ & 0.250 & 0.035 & $0.439 \pm 0.062$ \\
\hline 16 & $\begin{array}{l}\text { N } 23044.461^{\prime} \\
\text { E } 90023.762\end{array}$ & $0.188-0.306$ & 0.247 & 0.038 & $0.432 \pm 0.066$ \\
\hline 17 & $\begin{array}{l}\text { N } 23044.442^{\prime} \\
\text { E } 90023.619^{\prime}\end{array}$ & $0.120-0.250$ & 0.185 & 0.042 & $0.324 \pm 0.733$ \\
\hline 18 & $\begin{array}{l}\text { N } 23044.424^{\prime} \\
\text { E } 90023.625^{\prime}\end{array}$ & $0.110-0.290$ & 0.200 & 0.056 & $0.350 \pm 0.099$ \\
\hline 19 & $\begin{array}{l}\text { N } 23044.410^{\prime} \\
\text { E } 90023.632^{\prime}\end{array}$ & $0.120-0.260$ & 0.190 & 0.045 & $0.333 \pm 0.078$ \\
\hline 20 & $\begin{array}{l}\text { N } 23044.385^{\prime} \\
\text { E } 90023.626^{\prime}\end{array}$ & $0.120-0.260$ & 0.190 & 0.045 & $0.333 \pm 0.078$ \\
\hline 21 & $\begin{array}{l}\text { N } 23044.369^{\prime} \\
\text { E } 90023.622\end{array}$ & $0.140-0.530$ & 0.266 & 0.132 & $0.465 \pm 0.231$ \\
\hline 22 & $\begin{array}{l}\text { N } 23044.358^{\prime} \\
\text { E } 90023.632 \\
\end{array}$ & $0.130-0.260$ & 0.195 & 0.042 & $0.342 \pm 0.073$ \\
\hline 23 & $\begin{array}{l}\text { N } 23044.349^{\prime} \\
\text { E } 90023.635^{\prime}\end{array}$ & $0.120-0.250$ & 0.185 & 0.042 & $0.324 \pm 0.073$ \\
\hline 24 & $\begin{array}{l}\text { N } 23044.346^{\prime} \\
\text { E } 90023.635^{\prime}\end{array}$ & $0.140-0.440$ & 0.236 & 0.075 & $0.413 \pm 0.132$ \\
\hline 25 & $\begin{array}{l}\text { N } 23044.307 \\
\text { E } 90023.643\end{array}$ & $0.120-0.620$ & 0.265 & 0.141 & $0.464 \pm 0.249$ \\
\hline 26 & $\begin{array}{l}\text { N } 23044.302^{\prime} \\
\text { E } 90023.658^{\prime}\end{array}$ & $0.110-0.270$ & 0.181 & 0.047 & $0.318 \pm 0.083$ \\
\hline 27 & $\begin{array}{l}\text { N } 23044.299^{\prime} \\
\text { E } 90023.672^{\prime}\end{array}$ & $0.120-0.310$ & 0.204 & 0.057 & $0.358 \pm 0.100$ \\
\hline 28 & $\begin{array}{l}\text { N } 23044.287^{\prime} \\
\text { E } 90023.691^{\prime}\end{array}$ & $0.140-0.320$ & 0.227 & 0.056 & $0.397 \pm 0.098$ \\
\hline 29 & $\begin{array}{l}\text { N } 23044.284^{\prime} \\
\text { E } 90023.712^{\prime}\end{array}$ & $0.020-0.230$ & 0.170 & 0.039 & $0.298 \pm 0.068$ \\
\hline 30 & $\begin{array}{l}\text { N } 23044.290^{\prime} \\
\text { E } 90023.716^{\prime}\end{array}$ & $0.136-0.306$ & 0.223 & 0.052 & $0.391 \pm 0.090$ \\
\hline 31 & $\begin{array}{l}\text { N } 23044.291^{\prime} \\
\text { E } 90023.736^{\prime}\end{array}$ & $0.136-0.258$ & 0.197 & 0.040 & $0.351 \pm 0.070$ \\
\hline 32 & $\begin{array}{l}\text { N } 23044.309^{\prime} \\
\text { E } 90023.742^{\prime}\end{array}$ & $0.196-0.541$ & 0.288 & 0.084 & $0.504 \pm 0.148$ \\
\hline
\end{tabular}

Table 1: Real-time radiation dose rate monitoring around the BSMMU hospital campus in August-September 2019 
The annual effective dose ratio of the monitoring point no. 7 is very higher than that of others as shown in Fig. 1. The reason is that maximum number of the radiation generating equipments in this direction at BSMMU hospital campus was in 'on' condition when the real-time radiation dose rates were collected at monitoring point no. 7 .

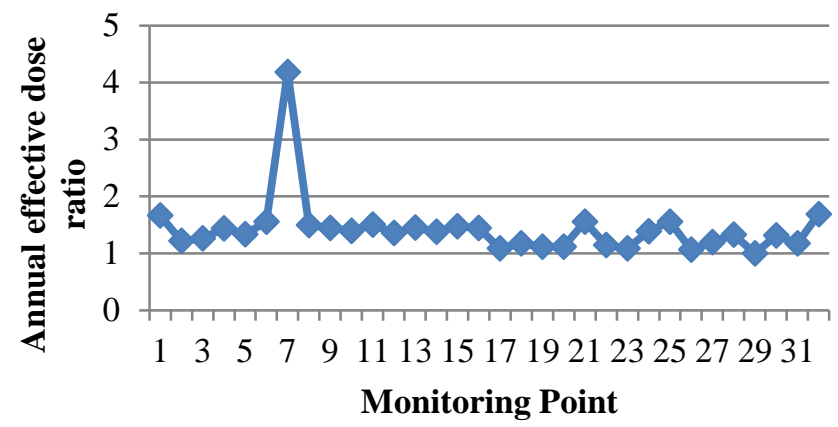

Fig. 1: Annual effective dose values normalized to the minimum annual effective dose for each MP.

1The frequency of the dose rate (nSv/hr) distribution around the BSMMU hospital campus in AugustSeptember 2019 is shown in Fig.2. The most of the real-time radiation dose rates were ranged from $0.170-0.322 \mu \mathrm{Sv} / \mathrm{hr}$ as depicted in the Fig.2.

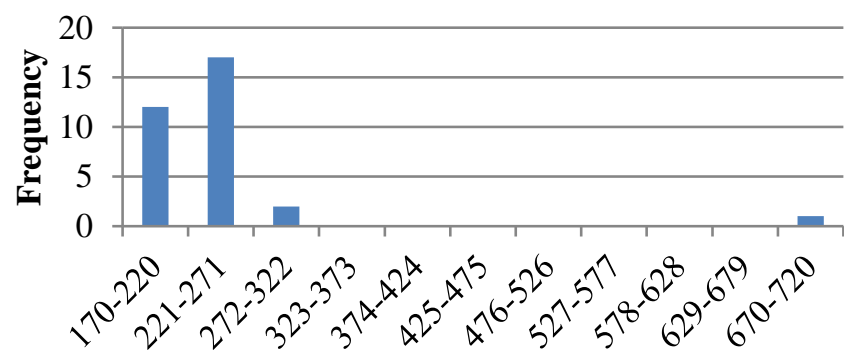

Absorbed dose rate (nSv/hr)

Fig. 2: The frequency of the dose rate (nSv/hr) distribution around the BSMMU hospital campus in August-September 2019

\section{ELCR on public health}

The term 'Excess life-time cancer risk' (ELCR) is defined as the probability that an individual will develop cancer over his/her life-time of exposure to ionizing radiation.

ELCR on public health around the BSMMU hospital campus based on the annual effective dose in August-September 2019 is shown in Fig. 3.

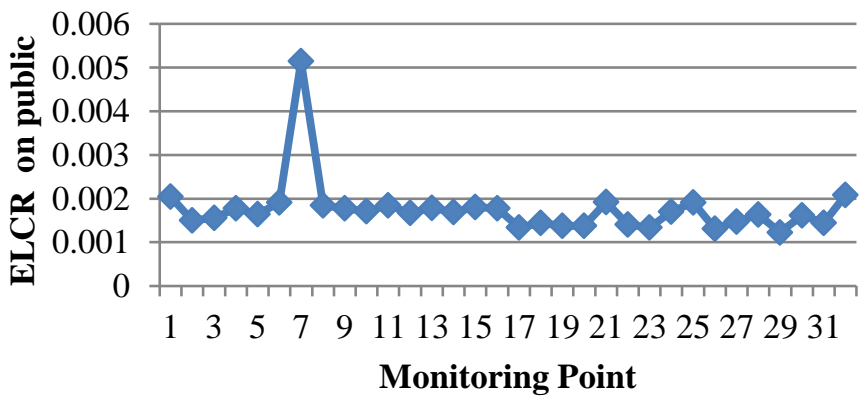

Fig. 3: ELCR on public around the BSMMU hospital campus based on annual effective dose in August-September 2019. 
From the Table 1, it was observed that mean annual effective dose on public around the BSMMU hospital campus is $0.368 \pm 0.097 \mathrm{mSv}$. The annual effective dose limit for public is $1 \mathrm{mSv}$ and this limit is applicable for planned exposure situation (ICRP, 2007; NSRC Rules, 1997). The ELCR on public around the BSMMU hospital campus were ranged from $0.881 \times 10^{-3}$ to $5.12 \times 10^{-3}$ with an average of $1.488 \times 10^{-3}$. The average ELCR on public around the BSMMU hospital campus is higher than that of the worldwide average value of $0.29 \times 10^{-3}$. The mean ELCR on public around the BSMMU hospital campus means that in every thousand people, one of them is at the risk of cancer caused by the scattered radiation exposure from the hospital without any knowledge of being exposed to ionizing radiation.

The progress of cancer due to ionizing radiation from the hospital radiation is not an immediate effect. It may take many years to develop cancer if it develops at all. It is found in literature (Temaugee et al, 2014) that after exposure to ionizing radiation; cancer may occur with some increasing frequency and can only be detected by epidemiological study. The period between ionizing radiation exposure and the detection of cancer is known as the latent period and this could take many years. The cancer may occur only when the individual has reached an advanced age for maximum cases.

\begin{tabular}{|c|c|c|c|c|c|c|}
\hline $\begin{array}{l}\text { Name of hospital/ } \\
\text { Nuclear Facility }\end{array}$ & $\begin{array}{l}\text { Range } \\
(\mu \mathrm{Sv} / \mathrm{hr})\end{array}$ & $\begin{array}{l}\text { Mean dose } \\
\text { rate }(\mu \mathrm{Sv} / \mathrm{hr})\end{array}$ & $\begin{array}{c}\text { Annual range/Mean } \\
\text { annual effective } \\
\text { dose (mSv) }\end{array}$ & $\begin{array}{l}\text { ELCR } \\
\mathrm{X} 10^{-3}\end{array}$ & Country & Reference \\
\hline $\begin{array}{l}\text { Dhaka Medical } \\
\text { College Hospital }\end{array}$ & $0.02-0.58$ & $0.17 \pm 0.04$ & $\begin{array}{c}0.21-.43 / \\
0.31 \pm 0.10\end{array}$ & $0.84-1.83$ & Bangladesh & Mim FS et al., 2020 \\
\hline Teaching Hospital & - & - & $0.03-0.32$ & - & Nigeria & Edith N I et al., 2018 \\
\hline $\begin{array}{l}\text { Rajasthan Atomic } \\
\text { Power Station }\end{array}$ & - & - & $0.63 \pm 0.15$ & - & India & \multirow[t]{4}{*}{ Chougaonkar M P et al., 2008} \\
\hline $\begin{array}{l}\text { Kakrapar Atomic } \\
\text { Power Station }\end{array}$ & - & - & $0.53 \pm 0.08$ & - & India & \\
\hline $\begin{array}{l}\text { Narora Atomic } \\
\text { Power Station }\end{array}$ & - & - & $1.2 \pm 0.12$ & - & India & \\
\hline $\begin{array}{l}\text { Kaiga Generating } \\
\text { Station }\end{array}$ & - & - & $0.51 \pm 0.11$ & - & India & \\
\hline $\begin{array}{l}\text { Nuclear } \\
\text { Establishment }\end{array}$ & $0.11-0.21$ & $0.15 \pm 0.03$ & $0.15-0.30$ & - & Nigeria & Oyeyinka O D et al., 2012 \\
\hline $\begin{array}{l}\text { Nuclear } \\
\text { Installations }\end{array}$ & $0.14-0.27$ & $0.19 \pm 0.05$ & $0.19-0.38$ & - & Ghana & Amekudzie A et al., 2011 \\
\hline $\begin{array}{l}\text { University of Port } \\
\text { Harcourt Teaching } \\
\text { Hospital, Rivers } \\
\text { State }\end{array}$ & $0.08-0.20$ & - & $0.31 \pm 0.002$ & $0.46-1.09$ & Nigeria & Ononugbo C.P. et al., 2016 \\
\hline $\begin{array}{l}\text { Nuclear Installa- } \\
\text { tion }\end{array}$ & $0.05-0.32$ & $0.11-0.19$ & $0.14-0.24$ & - & Bangladesh & Moontaha S et al., 2018 \\
\hline \multirow[t]{2}{*}{$\begin{array}{l}\text { Kwali General } \\
\text { Hospital }\end{array}$} & $0.10-0.12$ & $0.108 \pm 0.003$ & $0.189 \pm 0.005$ & - & Nigeria & James I.U. et al., 2015 \\
\hline & - & 0.274 & 0.48 & 0.29 & $\begin{array}{l}\text { Worldwide } \\
\text { average }\end{array}$ & UNSCEAR, 2008 \\
\hline $\begin{array}{l}\text { Bangabandhu } \\
\text { Sheikh Mujib } \\
\text { Medical } \\
\text { University }\end{array}$ & $0.020-2.45$ & $0.211 \pm 0.094$ & $\begin{array}{c}0.222-1.247 / \\
0.368 \pm 0.097\end{array}$ & $\begin{array}{c}0.881- \\
5.12\end{array}$ & Bangladesh & This study \\
\hline
\end{tabular}

Table 2: Comparison of dose rate, annual effective dose \& ELCR on public around the BSMMU hospital with other authors.

\section{CONCLUSION}

The real-time radiation dose rate monitoring in \& around the hospital is a very essential in order to control the quality of the CT scanners, X-ray machines, PET-CT scanners, linear accelerator and many other radiation generating equipments in the hospital. The real-time radiation monitoring in $\&$ around the hospital would help to ensure the protection of the radiation worker, public and the patients from undue radiation hazard. The real-time radiation monitoring is a direct signal of incorrect use of technical parameters of the radiation generating equipments or equipments malfunction. The ELCR on public around the BSMMU hospital is higher than that of the worldwide average. It is observed from the study that in every thousand people, one of them is at the risk of cancer caused by the scattered radiation exposure from the hospital without any knowledge of being exposed to ionizing radiation. The real- 
time radiation monitoring and estimation of radiation risk on public around the nuclear $\&$ radiological facilities have become great concern for the protection of public and the environment.

\section{Acknowledgement}

This research is funded by the Ministry of Science and Technology, Government of Bangladesh under the Special Research Allocation Project 2019-2020 \& 2020-2021 (the grant serial no. 523 MS \& 519 MS).

\section{REFERENCE}

Amekudzie A., Emi-Reynolds G., Kpeglo D.O., Mensah C.K., Gyekye P.K., Lawluvi H., Gbormittah S.V., Owusu E. (2011) "Determination of dose rate levels around nuclear installations in Ghana", International Journal of Science and Technology, Vol.1(3), pp144-147.

Ateba J.F.B., Ateba P.O., Ben-Bolie G.H., Abiama P.E., Abega C.R., Mvondo S. (2010) "Natural background dose measurements in South Cameroon," Radiation Protection Dosimetry, Vol. 140(1), pp 81-88. https://doi.org/10.1093/rpd/ncq035

Bangabandhu Sheikh Mujib Medical University (BSMMU) hospital, website, https://bsmmu.edu.bd/ (accessed 05 January, 2021)

Brenner DJ, Hall EJ. (2007) "Computed tomography: an increasing source of radiation exposure”, N. Engl. J. Med., Vol. 357(22), pp.2277-2284.

Chougaonkar M.P., Shetty P.G., Mayya Y.S., Puranik V.D., Joshi M.L., Kushwaha H.S. (2008) "Environmental gamma radiation monitoring around nuclear power stations in India, An Indian Scenario", Journal of Nuclear Science and Technology, Supplement 5, pp 619-622.

Edith N. I., Philomina O.C. (2018) "Estimation of radiation dose rate of radiological unit personnels in some teaching hospitals in Southern Nigeria", Radiation Science and Technology, Vol. 4(4), pp22-28.

Hazrati S., Sadeghi H., Amani M., Alizadeh B., Fakhimi H., Rahimzadeh S. (2010) "Assessment of gamma dose rate in indoor environments in selected districts of Ardabil Province, Northwestern Iran", International Journal of Occupational Hygiene, Vol.2(1), pp 42-45.

ICRP (2007), "Recommendations of the ICRP: Annals of the ICRP (International Commission on Radiological Protection)", Vol. 37, pp.2-4.

James I.U., Moses I.F., Vandi J.N., Ikoh U.E. (2015) "Measurement of indoor and outdoor background levels of Kwali General Hospital, Abuja", J. Appl. Sci. Environ. Manage., Vol. 19(1), pp89-93.

Mettler F.A. Jr., Bhargavan M., Faulkner K., et al. (2009) "Radiologic and nuclear medicine studies in the United States and worldwide: frequency, radiation dose, and comparison with other radiation sources-1950-2007", Radiology, Vol. 253(2), pp520-531.

Mim F. S., Rahman M. S., Tareq S. M., Yeasmin S.(2020), “Assessment of Radiation Hazard on Public Health at Indoor and Outdoor Environment of DMCH Campus, Dhaka, Bangladesh”, ABC Research Alert, Vol. 8(2), pp. 6977.

Moontaha S., Rahman M.S., Islam M.S., Yeasmin S. (2018) "Real-time environmental gamma radiation dose rate measurement around major nuclear and radiological facilities in Bangladesh", International Journal of Scientific Research and Management, Vol. 6(3), pp39-49.

NSRC (1997), (The Nuclear Safety and Radiation Control) Rules of Bangladesh (SRO No. 205-Law/97).

NCRP (2009), the National Council on Radiation Protection \& Measurements, Report No. 160, Bethesda, MD 208143095, USA.

Ononugbo C., Avwiri O. G. (2016) "Evaluation of effective dose and excess lifetime cancer risk from indoor and outdoor gamma dose rate of university of Port Harcourt Teaching Hospital, Rivers State," Scientia Africana, Vol. 15(1). https://www.ajol.info/index.php/sa/article/view/156472

Owner's Manual, GARMIN eTrex HC Series, available at https://static.garmincdn.com/pumac/eTrexLegendHCx_OwnersManual.pdf

Oyeyinka O.D., James I.U., Akueche E.C., Shonowo O.A., Adesanmi C.A. (2012) "Estimation of radiation dose rate levels around a nuclear establishment in Abuja, North Central, Nigeria", Science and technology, Vol. 2(6), pp 163-167.

Temaugee S. T., Daniel T. A., Oladejo K. O., Daniel S. (2014) “Assessment of Public Awareness of the Detrimental Effects of Ionizing Radiation in Kontagora, Niger State", Nigeria", International Journal of Science and Technology, Vol. 4(7), pp.134-141.

UNSCEAR (2000), "United Nations Scientific Committee on the Effects of Atomic Radiation. Sources and Effects of Ionizing Radiation Report to General Assembly, with Scientific Annexes (New York: United Nations, United Nations Sales Publication E.00.IX.3). 
UNSCEAR (2008), "United Nations Scientific Committee on the Effects of Atomic Radiation. Sources and Effects of Ionizing Radiation Report to General Assembly, with Scientific Annexes, Vol. I, Annex-A, Page No. 23 (New York: United Nations)

UNSCEAR (1993), "United Nations Scientific Committee on the Effects of Atomic Radiation Sources and Effects of Ionizing Radiation Report to General Assembly, with Scientific Annexes (New York: United Nations).

UNSCEAR (1988), "United Nations Scientific Committee on the Effects of Atomic Radiation, sources, effects and risks of ionizing radiation", (United Nations, New York).

University of California (2021), Department of Radiology \& Biomedical Imaging, San Francisco, Web address: https://radiology.ucsf.edu/patient-care/patient-safety/radiation-safety/risks-of-radiation

User Manual GAMMA SCOUT, available at https://www.gamma-scout.com/EN/Handbuch.php

World Bank Report (2018), Web address: https://data.worldbank.org/indicator/SP.DYN.LE00.IN?locations=BD (accessed 30 March 2021) 